\title{
The Interplay between Prosody and Syntax in Sentence Processing: The Case of Subject- and Object-control Verbs
}

\author{
Sara Bögels ${ }^{1}$, Herbert Schriefers ${ }^{1}$, Wietske Vonk ${ }^{1,2}$, \\ Dorothee J. Chwilla' ${ }^{1}$, and Roel Kerkhofs ${ }^{1}$
}

\begin{abstract}
This study addresses the question whether prosodic information can affect the choice for a syntactic analysis in auditory sentence processing. We manipulated the prosody (in the form of a prosodic break; PB) of locally ambiguous Dutch sentences to favor one of two interpretations. The experimental items contained two different types of so-called control verbs (subject and object control) in the matrix clause and were syntactically disambiguated by a transitive or by an intransitive verb. In Experiment 1 , we established the default off-line preference of the items for a transitive or an intransitive disambiguating verb with a visual and an auditory fragment completion test. The results suggested that subject- and object-control verbs differently affect
\end{abstract}

\section{INTRODUCTION}

When processing a sentence, several sources of information (e.g., syntactic, semantic, and discourse information) are available to arrive at the correct interpretation of the sentence. The majority of research on sentence processing has focused on reading. However, auditory sentence processing is probably more frequent in everyday life. Furthermore, spoken sentences also contain (explicit) prosodic information as an additional potential source that can help sentence interpretation. Prosody can be defined as "those phenomena that involve the acoustic parameters of pitch, duration and intensity" (Ladd \& Cutler, 1983, p. 1). The present study addresses the question whether prosody can affect the choice for a syntactic parse in locally ambiguous sentences.

Off-line methods, such as questions after hearing a globally ambiguous sentence, have revealed that the place of prosodic boundaries and pitch accents can determine the interpretation of a sentence (e.g., Schafer, Carter, Clifton, \& Frazier, 1996; Schafer, 1995; Streeter, 1978). Prosody can also help to choose between two possible endings for a locally ambiguous sentence (Stirling \& Wales, 1996; Beach, 1991). Other studies used cross-modal naming, an on-line method. Most of these studies (Kjelgaard \&

\footnotetext{
${ }^{1}$ Radboud University Nijmegen, The Netherlands, ${ }^{2}$ Max Planck Institute for Psycholinguistics, Nijmegen, The Netherlands
}

the syntactic structure that listeners expect. In Experiment 2, we investigated these two types of verbs separately in an on-line ERP study. Consistent with the literature, the PB elicited a closure positive shift. Furthermore, in subject-control items, an N400 effect for intransitive relative to transitive disambiguating verbs was found, both for sentences with and for sentences without a PB. This result suggests that the default preference for subjectcontrol verbs goes in the same direction as the effect of the PB. In object-control items, an N400 effect for intransitive relative to transitive disambiguating verbs was found for sentences with a PB but no effect in the absence of a PB. This indicates that a $\mathrm{PB}$ can affect the syntactic analysis that listeners pursue.

Speer, 1999; Warren, Grabe, \& Nolan, 1995; MarslenWilson, Tyler, Warren, Grenier, \& Lee, 1992; but see Rösler, Friederici, Pütz, \& Hahne, 1993) found that prosody can affect on-line parsing preferences. However, with this method, sentences are presented partially and participants have to perform a rather unnatural task. ERPs can counter these problems and, moreover, provide a measure of processing across the whole sentence.

The present study builds on an ERP study by Steinhauer, Alter, and Friederici (1999) on the processing of auditorily presented German sentences as in the following items:

(1) Peter verspricht Anna zu arbeiten... (Peter promises Anna to work...)

(2) Peter verspricht Anna zu entlasten... (Peter promises to support Anna...)

Note that in German (in contrast to English), Items 1 and 2 are the same up to the second verb and are syntactically disambiguated by this verb. In Item 1, Anna is the indirect object of the verb verspricht. This becomes clear at the verb arbeiten because this is an intransitive verb. In Item 2, by contrast, Anna must be the direct object of the verb entlasten because this is an obligatorily transitive verb. According to Steinhauer et al. (1999), without other cues, Item 2 will lead to a garden-path effect because Anna is initially regarded as the indirect object of verspricht. This initial preference is thought 
to be driven by the minimal attachment principle (Frazier, 1987; see Steinhauer, 2003, p. 145). Steinhauer et al. also proposed that a prosodic break (PB) after verspricht can provide an earlier disambiguation, before the second verb, that should reverse this garden-path effect and lead to processing difficulty at the intransitive verb arbeiten in Item 1 relative to the transitive verb entlasten in Item 2.

A PB or a boundary consists of a pause, a prefinal lengthening of the last stressed syllable before the pause, and a boundary tone (see, e.g., Kjelgaard \& Speer, 1999). A PB after verspricht provides a break between verspricht and Anna, which is likely to prevent Anna from being considered as the indirect object of verspricht. If this is the case, the PB disambiguates the sentence toward the structure in Item 2, and the intransitive verb arbeiten (as in Item 1) causes a garden-path effect.

In line with this reasoning, Steinhauer et al. (1999) found a biphasic N400-P600 effect in response to the disambiguating intransitive verb arbeiten relative to the transitive verb entlasten when a $\mathrm{PB}$ was present after verspricht. The N400 effect was regarded as a reflection of lexical reaccess to confirm the violation of the intransitive argument structure, the P600 effect as a structural revision. These results were taken to show a prosodyinduced garden-path effect. Moreover, the closure positive shift (CPS; Steinhauer et al., 1999) was discovered at the position of the $\mathrm{PB}$ for sentences with a $\mathrm{PB}$, whereas this ERP component was absent at the equivalent position in sentences without a PB.

The present study uses similar materials as Steinhauer et al. (1999) in Dutch, as in the following items:

(3) De leerling (NP1) bekende (V1) de leraar (NP2) te hebben gespiekt (V2 intransitive $).$. [The pupil (NP1) confessed (V1) (to) the teacher (NP2) to have cheated ( $\left.V 2_{\text {intransitive }}\right) \ldots$ J

(4) De leerling (NP1) bekende (V1) de leraar (NP2) te hebben opgesloten (V2 transitive)... [The pupil (NP1) confessed (V1) to have locked up (V2 transitive) the teacher (NP2)...]

Note that the word order is similar as in German. The first verb (V1; bekende, "confessed" in Items 3 and 4 and verspricht, "promises" in Items 1 and 2) is a so-called control verb. In the linguistic literature, subject-control (SC) verbs and object-control (OC) verbs are distinguished (e.g., Comrie, 1985). The verb bekende ("confessed") in Items 3 and 4 is an SC verb because the subject of this verb (de leerling, "the pupil") takes on the function of subject of the following infinitive complement (bebben gespiekt, "have cheated" in Item 3 or bebben opgesloten, "have locked up" in Item 4). The verb adviseerde ("advised") in Items 5 and 6 is an OC verb because its (explicit or implicit) indirect object takes on the function of subject of the following infinitive complement (slapen, "sleep" in Item 5 and ondersteunen, "support" in Item 6).
(5) De chirurg (NP1) adviseerde (V1) de vrouw (NP2) te

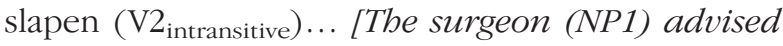
(V1) the woman (NP2) to sleep (V2 intransitive)...]

(6) De chirurg (NP1) adviseerde (V1) de vrouw (NP2) te ondersteunen $\left(\mathrm{V} 2_{\text {transitive }}\right) \ldots$ [The surgeon (NP1) advised (V1) to support (V2 transitive) the woman (NP2)...]

If the sentence contains an intransitive V2 such as Item 5 , NP2 (de vrouw, "the woman") is the explicit object of V1 and the understood subject of V2 (slapen, "sleep"). In case of a transitive V2, as in Item 6, the object of V1 is not mentioned. This implicit object is the understood subject of V2 (ondersteunen, "support"). In the following, items containing an SC V1 are called SC items and items containing an OC V1 are called OC items. In the materials of Steinhauer et al. (1999), five SC and seven OC verbs were used (personal communication). In contrast to Steinhauer et al. who did not differentiate between SC and OC verbs and thus implicitly assumed that the two verb types are processed in the same way, in the present study we investigate whether differences in processing exist between SC and OC items.

We presented participants with sentences like Items 3 to 6 both with and without a PB after V1. This yields a design in which the two factors PB (present or absent) and Disambiguating Verb (transitive or intransitive) are fully crossed. This design differs from the one used by Steinhauer et al. (1999), who presented the German equivalents of Items 3 and 5 with and without a PB but the equivalents of Items 4 and 6 only with a PB.

In the present ERP study (Experiment 2), we expect to find a CPS in response to the PB (e.g., Kerkhofs, Vonk, Schriefers, \& Chwilla, 2007, 2008; Isel, Alter, \& Friederici, 2005; Pannekamp, Toepel, Alter, Hahne, \& Friederici, 2005; Steinhauer \& Friederici, 2001; Steinhauer et al., 1999).

The results at the disambiguating verb (V2) should depend on the default analysis that listeners pursue. As already indicated, Steinhauer et al. (1999) assumed that NP2 will by default be interpreted as the indirect object of V1 and an intransitive disambiguating verb should fit this preference. However, they could not test whether this assumed default preference really holds because in their design, sentences with a transitive V2 were never presented without a $\mathrm{PB}$. This implies that the relevant comparison to establish the default preference, no-break transitive versus no-break intransitive, was not included in their design. With a fully crossed design, we can test this assumed default preference.

Moreover, given potential differences between the two types of control verbs, it is not certain whether a preferred default analysis will be the same for SC and OC items. To our knowledge, no earlier studies explicitly contrasted the processing of SC and OC verbs. In Experiment 1, we first establish the off-line default preference for an intransitive versus a transitive disambiguating verb in SC and OC items in a visual and in an auditory fragment completion test 
(FCT). The auditory FCT additionally provides us with the possibility to look at the potential off-line effects of the absence or presence of a PB after V1.

\section{EXPERIMENT 1}

\section{Methods}

\section{Participants}

Participants were 30 native speakers of Dutch (four males), with no reading problems and with a mean age of 20.2 years for the visual FCT and 20 other native speakers of Dutch (one male), with a mean age of 21 years and with no reading and/or hearing problems for the auditory FCT. The participants were paid or received course credit for their participation.

\section{Materials}

As a starting point, we searched for all Dutch control verbs suitable for our experimental sentences. We found 14 SC verbs and 10 OC verbs. Because of the relatively small number of available control verbs in Dutch, we created two different items for each control verb. An example of an SC and an OC item can be found in Table 1. All sentences were of the form [NP1][V1] [NP2][V2], fol- lowed by at least four words. V1 was always a control verb. In one version of each item, V2 was intransitive, and in the other version, it was obligatorily transitive. In some of the SC items, an auxiliary was placed between NP2 and V2 to make the sentences sound more natural. See Appendix A for the resulting 28 SC and 20 OC items.

For the auditory FCT, these items were recorded by a female native speaker of Dutch in two versions: with a transitive and an intransitive V2. She first read a sentence silently for herself and then out loud. Each sentence was recorded three times. Sentences with a transitive V2 were produced with a PB after V1 (see sentences C1 and C2 in Table 1), and sentences with an intransitive V2 were produced without such a PB (see sentences B1 and B2 in Table 1). All sentences were produced with a PB after V2. For every item, the best token of each version was chosen by the experimenters based on intuition. This token was cut in two parts in the silence before the [t] of te ("to") preceding V2. Only the first part was used. This resulted in two different tokens of the form [NP1] [V1] [NP2] per item, one with and one without a PB after V1.

We performed acoustic analyses on these sentence parts (for means and SDs, see Table 2) in the form of ANOVAs with PB (break, no-break) as within-item factor and Control (subject, object) as between-item factor. Analyses on the length and pitch range of NP1 and

Table 1. Examples of the Experimental Sentences

Subject control (SC)

A1 Break, Intransitive V2

B1 No break, Intransitive V2

C1 Break, Transitive V2

D1 No break, Transitive V2

Object control (OC)

A2 Break, Intransitive V2

B2 No break, Intransitive V2

C2 Break, Transitive V2

D2 No break, Transitive V2
[De leerling bekende] [de leraar ${ }^{1}$ te hebben $^{2}$ gespiekt] [tijdens het eerste uur.] [The pupil confessed] [(to) the teacher to have cheated] [during the first bour.]

[De leerling bekende de leraar ${ }^{1}$ te hebben $^{2}$ gespiekt] [tijdens het eerste uur.] [The pupil confessed (to) the teacher to have cheated] [during the first hour.] [De leerling bekende] [de leraar ${ }^{1}$ te hebben ${ }^{2}$ opgesloten] [tijdens het eerste uur.] [The pupil confessed] [to have locked up the teacher] [during the first bour.] [De leerling bekende de leraar ${ }^{1}$ te hebben ${ }^{2}$ opgesloten] [tijdens het eerste uur.] [The pupil confessed to have locked up the teacher] [during the first hour.]

[De chirurg adviseerde] [de vrouw ${ }^{1} \mathrm{te}^{2}$ slapen] [voor de zware operatie.] [The surgeon advised] [the woman to sleep] [before the heavy surgery.]

[De chirurg adviseerde de vrouw $^{1}$ te $^{2}$ slapen] [voor de zware operatie.]

[The surgeon advised the woman to sleep] [before the beavy surgery.]

[De chirurg adviseerde] [de vrouw ${ }^{1} \mathrm{te}^{2}$ ondersteunen] [voor de zware operatie.]

[The surgeon advised] [to support the woman] [before the beavy surgery.]

[De chirurg adviseerde de vrouw ${ }^{1} \mathrm{te}^{2}$ ondersteunen] [voor de zware operatie.]

[The surgeon advised to support the woman] [before the heavy surgery.]

Intonational phrases, separated by PBs, are indicated by square brackets. For the visual FCT, the sentences were presented until Position 2 , and for the auditory FCT, they were presented auditorily until Position 1 and visually from Positions 1 to 2 . English translations are given in italics. 
Table 2. Means and SDs for the Acoustic Analyses, Separately for the SC and the OC Items

\begin{tabular}{|c|c|c|c|c|}
\hline & \multicolumn{2}{|c|}{ SC Items } & \multicolumn{2}{|c|}{ OC Items } \\
\hline & $M_{\text {break }}(S D)$ & $M_{\text {no-break }}(S D)$ & $M_{\text {break }}(S D)$ & $M_{\text {no-break }}(S D)$ \\
\hline NP1 length (msec) & $464(106)$ & $468(104)$ & $524(133)$ & $532(133)$ \\
\hline NP1 pitch range (Hz) & $54(18)$ & $55(19)$ & $48(13)$ & $45(10)$ \\
\hline V1 unstressed length $(\mathrm{msec})^{\mathrm{a}}$ & $117(78)$ & $113(66)$ & $129(59)$ & $122(59)$ \\
\hline V1 stressed length $(\mathrm{msec})^{\mathrm{b}}$ & $498(76)$ & $301(72)$ & $442(75)$ & $273(63)$ \\
\hline Pause length & $308(85)$ & - & $327(70)$ & - \\
\hline
\end{tabular}

${ }^{\mathrm{a}} \mathrm{V} 1$ unstressed length = length of unstressed syllable(s) of V1 preceding the stressed syllable.

${ }^{\mathrm{b}} \mathrm{V} 1$ stressed length $=$ length of the stressed syllable and following unstressed syllable(s) of V1.

the length of the unstressed syllable(s) of V1 preceding the stressed syllable revealed no effects of PB ( $p$ s > $.06)$ or interactions between $\mathrm{PB}$ and Control $(F s<1)$. However, prefinal lengthening took place in the last stressed syllable of V1 and following unstressed syllables; these syllables were longer in the break condition than in the no-break condition, $F(1,42)=1142.26, p<$ $.001{ }^{1}{ }^{1}$ The prefinal lengthening was more pronounced in the SC items (197 msec) than in the OC items (169 msec), which is reflected in an interaction between PB and Control, $F(1,42)=6.91, p<.05$. Moreover, the pitch track was qualitatively different for the break and no-break sentences. In sentences with a PB, a boundary tone occurred on the last syllable before the pause, whereas in sentences without a PB, no boundary tone was present and pitch accents occurred on V1. This was the case for both SC and $\mathrm{OC}$ items. Furthermore, in the sentences with a PB, a pause was present between V1 and NP2, which did not differ in length between the SC and the OC items $(p>.20)$. No pause at this position was present in sentences without a PB. In summary, examination of the three features of the PB indicated that the first acoustic information about the PB becomes available not earlier than the last stressed syllable before the pause for both SC and OC items.

As filler sentences for both FCTs, 60 simple sentences were taken from Hagoort and Brown (1994). These sentences had one of two versions, with a high or with a low cloze noun (e.g., Jenny put the sweet in her [mouth high clozel pocket $t_{\text {low clozel }}$ after the lesson.). For the auditory FCT, these sentences were recorded by another female native speaker of Dutch.

\section{Design}

We looked at the preference for intransitive or transitive completions for SC and OC items. For the auditory FCT, we additionally included the factor PB. The items were presented in a pseudorandom order such that no more than three experimental items were presented in a row. Two lists were created by switching the halves of the experiment. Furthermore, in the auditory FCT, every ex- perimental item occurred once in one half of a list (with or without a $\mathrm{PB}$ ) and once in the other half of the list but in the other condition (without or with a PB).

\section{Procedure}

In the visual FCT, the experimental items were presented up to but not including the disambiguating V2 (up to Position 2 in Table 1). The filler items were presented up to, but not including, the high or low cloze word. The items were presented in a booklet, and participants had to write down their completions after each item. They were instructed to complete each sentence fragment in two correct and plausible ways. The first seven and the last five items in the booklet were filler items.

In the auditory FCT, participants had to complete the sentence fragments in one correct and plausible way. A warning beep preceded every item. The experimental items were presented auditorily via headphones up to and including NP2 (Position 1 in Table 1). The word te ("to") was not presented auditorily because coarticulation in the schwa of te would reveal information about the next phoneme. Following the auditory fragment, te or te plus auxiliary (Position 1 to Position 2 in Table 1) were presented visually on a computer screen, followed by a blank field in which participants typed their completion of the sentence. The filler fragments were presented auditorily up to one or two words before the high or low cloze noun (e.g., Jenny put the sweet for the example given above), and the remaining words (in her) were presented visually. The experiment started with a practice block and consisted of three blocks. Each block was preceded by three starter sentences and followed by a short pause.

\section{Results}

For the visual FCT, the first response was scored as either a transitive or an intransitive verb. When the verb provided in the first response could not be interpreted as exclusively transitive or intransitive in this context, we scored 
the second response. If this response was ambiguous as well, the corresponding participant's and item's scores were treated as a missing value (1.25\% of 1440 responses). OC items clearly received more intransitive completions than SC items, $t(46)=-9.13, p<.001$. SC items received $41 \%$ intransitive completions, which was not significantly different from $50 \%, t(27)=-1.79, p>.08$, whereas OC items showed an overwhelming intransitive preference (97\%) differing from 50\%, $t(19)=40.17, p<.001$. In Figure $1 \mathrm{~A}$, the distributions of intransitive completions for SC and $\mathrm{OC}$ items are presented, showing that they differ clearly and are in fact almost nonoverlapping.

Each completion in the auditory FCT was scored as transitive, intransitive, or ambiguous. The last category was discarded (11.0\% of 960 responses). An ANOVA was performed on the percentage of intransitive completions, with PB (break, no-break) as within-item factor and Control (subject, object) as between-item factor. OC items received more intransitive completions (break, 91\%; no-break, 78\%) than SC items (break, 10\%; no-break, 36\%), $F(1,46)=$ $132.64, p<.001$. More intransitive completions were given in the break than in the no-break conditions, $F(1,46)=$ $61.06, p<.001$, and this effect of PB was somewhat larger for SC than OC items, $F(1,46)=6.74, p<.05$. All preferences differed from $50 \%(p s<.05)$. Figure $1 \mathrm{~B}$ and $\mathrm{C}$ displays the distributions of intransitive completions for SC and OC items for the no-break and break conditions.

\section{Discussion}

The FCTs indicate a very strong preference for intransitive completions in OC items, whereas SC items show a slight preference for transitive completions. Comparing the two FCTs, the results for the visual FCT are very similar to the results for the no-break condition of the auditory FCT (see Figure 1A and B). Extrapolating these results to on-line processing, the FCTs suggest that for OC verbs that are not followed by a PB, a transitive V2 should lead to processing difficulty relative to an intransitive V2. In terms of Steinhauer et al. (1999), this would reflect a garden-path effect when the minimal attachment preference for an intransitive V2 is not confirmed at V2. By contrast, if a PB is present after the control verb (V1), the data by Steinhauer et al. would lead one to expect a reversed garden-path effect, showing processing difficulty for an intransitive V2
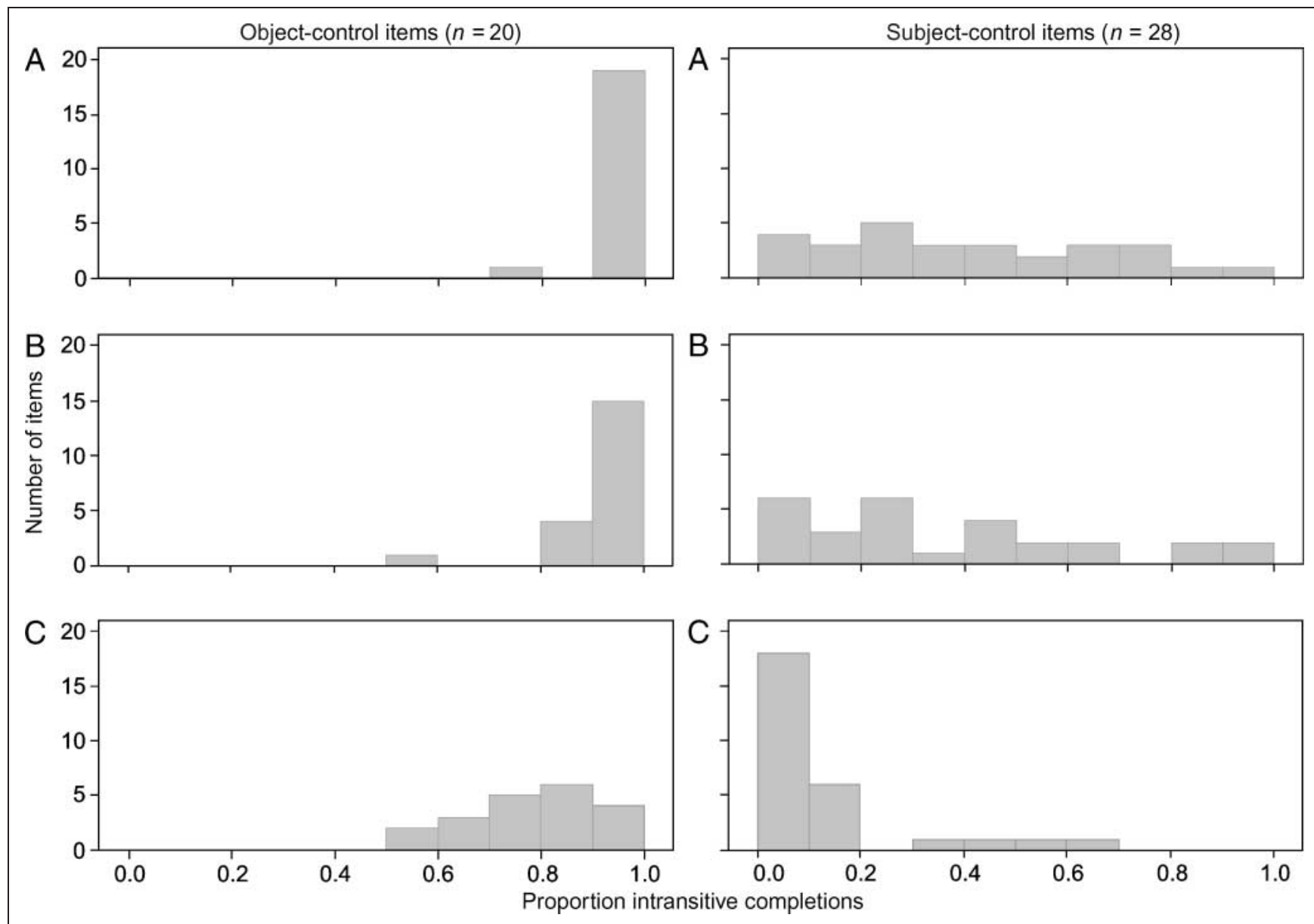

Figure 1. Distributions of items over the proportion of intransitive completions in the FCTs ( $x$-axis). The $y$-axis represents the number of items that fall in the respective proportion ranges. OC items $(n=20)$ are presented on the left, SC items $(n=28)$ on the right. Panel A displays the distribution of the visual FCT, panel B and C display the auditory FCT, in the no-break and the break condition, respectively. 
relative to a transitive V2. Two points should be noted in this context, however. First, the former prediction concerning a garden-path effect in the case of no PB could not be tested in the study of Steinhauer et al. due to the fact that they did not use a fully crossed design. Second, the auditory FCT data show that a PB after an OC V1 can reduce the preference for intransitive completions (to $78 \%$ ), but it clearly does not eliminate it or even reverse it to a transitive preference.

For SC verbs, the auditory FCT shows a very different pattern, namely, a preference for a transitive V2, present both in the no-break and in the break condition. In terms of on-line processing, an SC verb not followed by a PB should lead to processing difficulty for an intransitive relative to a transitive V2. The effect of a PB after V1 should go in the same direction. Therefore, it is questionable whether on-line data will show a strengthening of this effect by the PB. In Experiment 2, these predictions are tested using ERPs.

\section{EXPERIMENT 2}

\section{Methods}

\section{Participants}

Participants were 36 right-handed native speakers of Dutch, with no hearing problems. They were paid or received course credit for their participation. Excessive artifacts led to exclusion of 8 participants. The remaining 28 participants (five male) had a mean age of 21.7 years.

\section{Materials}

The materials for the ERP experiment were constructed from the recorded sentences for Experiment 1 (see Table 1, sentences $\mathrm{B}$ and $\mathrm{C}$ for example sentences). Of these sentences, we chose two tokens without a PB and with an intransitive V2 (sentences B1 and B2 in Table 1) and two tokens with a PB and a transitive V2 (sentences C1 and $\mathrm{C} 2$ in Table 1). After cutting these four chosen tokens in two parts before te ("to") preceding V2 (Position 1 in Table 1), only the first or the last part of each token was used. This resulted in two "first parts" of tokens (with and without PB; already used in the auditory FCT) and two "second parts" of tokens (with a transitive and with an intransitive V2). With these four parts, four new experimental tokens were created by cross-splicing: two tokens with a transitive V2 and two tokens with an intransitive V2, both with and without PB.

Next to these experimental sentences, 120 filler sentences were created, recorded, and cross-spliced. These consisted of locally ambiguous NP and S coordination sentences (see Kerkhofs et al., 2007). Also, 32 additional sentences were created, recorded, and cross-spliced, half of a similar type as the experimental items and half of the type of the filler items. Of these, 20 were used as a practice block before the experiment and 12 as starter sentences, two per block of the experiment (see Procedure section).

\section{Design}

The design contains two within-item factors, PB (break, no-break) and Structure (transitive V2, intransitive V2), and one between-item factor, Control (subject, object). Two separate subdesigns are present, one for the OC items and one for the SC items, each with the fully crossed factors PB and Structure. Four lists of experimental sentences were created. Each experimental item occurred in all four conditions in each list. This implies that every participant heard the same item four times. However, the (critical) disambiguating verb was only repeated twice for each item, once in a sentence with a PB and once in a sentence without a PB. Furthermore, we constructed the lists such that every item occurred only once in each quarter of a list. Counterbalancing ensured that across lists each item occurred in all four conditions across the four quarters. The conditions were counterbalanced within each list and each quarter such that every condition had the same mean rank over items. This ensured an even distribution of the different conditions of both the SC and the OC items over the experiment and over the four quarters.

The $112(28 \times 4)$ experimental SC sentences and the $80(20 \times 4)$ experimental OC sentences in each list were combined with the 120 filler sentences to a total of 312 sentences. For each list, a pseudorandom order of the experimental and filler sentences was determined with the restriction that no more than three experimental items or two filler items were presented in a row.

\section{Procedure}

The participants were tested in a soundproof and dimly lit room and heard the sentences over headphones. A written and an oral instruction informed them about the course of the experiment. They were instructed to listen carefully and to try to imagine what the sentences were about. A trial started with a warning beep of $100 \mathrm{msec}$. The sentence started 500 msec after onset of the warning beep. Participants were asked to look at a fixation cross and to avoid eye blinks and eye movements from the warning beep until the offset of the sentence. They were allowed to make eye movements in a period of $4 \mathrm{sec}$ between the offset of a sentence and the next warning beep. In this interval, normal background noise (recorded in between the sentences during the recording) was presented because a period of complete silence between the sentences sounds unnatural.

First, participants were trained to fixate on the screen without making any eye movements, in a practice block of 20 sentences. Then six experimental blocks were presented, each consisting of two starter sentences and 52 experimental and filler sentences. Immediately after an experimental block, participants had to decide which of 
two written sentences on a piece of paper they had heard in the previous block and which not. Both sentences had the same structure as the items in the experiment, but only one had actually occurred in the previous block. This task was not very demanding and was administered to ensure that the participants paid attention while listening to the sentences.

\section{Apparatus}

The EEG was recorded from 25 tin electrodes. Electrode positions were a subset of the international 10\% system. Three midline electrodes (Fz, $\mathrm{Cz}$, and $\mathrm{Pz})$ and 22 lateral electrodes (AF7/8, F7/8, F3/4, FC3/4, T7/8, C3/4, CP5/6, $\mathrm{P} 7 / 8, \mathrm{P} 3 / 4$, and $\mathrm{PO} 7 / 8$ ) were used, as in earlier auditory ERP studies (e.g., Kerkhofs et al., 2007). The left mastoid was used as a reference during the recording, but the signal was re-referenced to software linked mastoids before the analysis. Eye blinks were monitored by vertical EOG electrodes above and below the right eye and horizontal eye movements by two electrodes at the outer canthi. Electrode impedance was kept below $5 \mathrm{k} \Omega$ for EOG electrodes and below $3 \mathrm{k} \Omega$ for EEG electrodes. Signals were amplified with a time constant of $8 \mathrm{sec}$ and a band-pass filter of 0.05 to $100 \mathrm{~Hz}$ and digitized with a 16-bit A/D converter at a sampling frequency of $500 \mathrm{~Hz}$.

\section{Results}

\section{Performance on Test Questions}

Of the 28 participants, 26 participants identified the right sentence in all six cases and the remaining two participants made only one error.

\section{Data Analysis for ERP data}

The EEG data were filtered with a 30-Hz low-pass filter and afterward time locked to the critical positions in the sentence. In previous studies, ERPs have been time locked to different positions in the sentence to measure the effect of a PB. Steinhauer et al. (1999) time locked to sentence onset and determined CPS onset relative to the average position of the pause in the sentence. A disadvantage of this method is considerable latency variability across items in the onset of the pause. This problem is avoided by Kerkhofs et al. (2007) by time locking to the onset of the pause in the conditions with a PB, the offset of V1 in the present experiment. This time-locking point has the disadvantage that information about other features of the PB (preceding the pause), such as prefinal lengthening and boundary tone, is already available before pause onset. These features are presumably important in eliciting the CPS because a PB from which the pause is removed can still elicit a CPS (Steinhauer et al., 1999). Therefore, we chose an intermediate timelocking point in the sentence, located just before prefinal lengthening and boundary tone started. On the basis of the acoustic analyses reported in the Materials section of Experiment 1, we identified this position as the onset of the last stressed syllable before the pause. ${ }^{2}$ This point leads to less latency variability in onset of the pause across items than sentence onset while the acoustic markers of the PB that precede the pause are taken into account. We computed averages for $2000 \mathrm{msec}$ after onset of this point. To compare it to the points used in previous research, Appendix B shows grand average waveforms for those points. To investigate the effects at the disambiguation, averages were computed for $1000 \mathrm{msec}$ after the onset of the disambiguating verb. A period of $150 \mathrm{msec}$ before each time-locking point was used as baseline.

Epochs with excessive EEG $(>100 \mu \mathrm{V})$ and/or EOG amplitude $(>75 \mu \mathrm{V})$ were excluded from the analyses. For the analyses of the CPS, transitive and intransitive conditions with a PB and transitive and intransitive conditions without a PB were taken together because the first parts of the sentences (NP1, V1, and NP2) consisted of the same tokens. A mean of 43 trials (of a maximum of 56 trials, $S D=9.7$ ) per participant and condition remained for SC items and a mean of 32 trials (of a maximum of 40 trials, $S D=5.8$ ) for OC items. For the analyses on the disambiguating verb, a mean of 27 trials (of a maximum of 28 trials, $S D=1.7$ ) remained for SC items and a mean of 19 (of a maximum of 20 trials, $S D=1.4$ ) for OC items. On average, the number of removed trials did not differ more than one trial between the to be compared conditions.

To quantify the different ERP components, time windows were chosen based on visual inspection and/or previous literature. For the analyses of the CPS, PB (break, no-break) was entered as a critical factor. For the analyses on the disambiguating verb, Structure (transitive or intransitive) and PB were entered as critical factors. Initially, overall analyses were performed on the data of the SC and OC items together, with the additional critical factor Control (subject, object). For the overall analyses on the disambiguating verb, we only report interactions of Control with the other critical factors. In the next step, we performed separate analyses for the SC and the OC items. Two different types of multivariate repeated measures analyses (e.g., Vasey \& Thayer, 1987) were performed for all time-locking points. Next to the critical factor(s), the MANOVA for the midline electrodes included the factor Midline Electrode (Fz, Cz, and $\mathrm{Pz}$ ) and the MANOVA for the lateral electrodes included the factors Hemisphere (left and right), ROI (anterior and posterior), and Electrode. The factors Hemisphere and ROI divided the electrodes into four quadrants with four electrodes each: left anterior (AF7, F7, F3, and FC3), right anterior (AF8, F7, F4, and FC4), left posterior (CP5, P3, P7, and PO7), and right posterior (CP6, P4, P8, and PO8). Three additional electrodes on either hemisphere (left: FT7, T7, and C3; right: FT8, T8, and C4) were not included in the overall analyses. For completeness, we do include these electrodes in the figures and report effects for these electrodes when follow-up analyses for the single electrodes 
are reported. In all analyses, we focus on effects including the critical factor(s) and only these are reported. For the figures only, and not for the analyses, the grand average waveforms were smoothed off-line using a 5-Hz lowpass filter.

\section{Prosodic Break}

In Figure 2, grand average waveforms for all electrodes are presented, separately for the SC and the OC items, time locked to the onset of the last stressed syllable before the pause. Visual inspection suggests a clear CPS for both types of control items. The CPS starts almost immediately after pause onset (around $500 \mathrm{msec}$ after stressed syllable onset) and peaks around $500 \mathrm{msec}$ after pause onset. On the basis of these observations, a time window of 300 to $700 \mathrm{msec}$ after pause onset, corresponding to roughly 800 to 1200 msec after onset of the stressed syllable, was chosen to analyze the CPS. Furthermore, a (small) reversed effect before the CPS can be observed at some electrodes (e.g., CP6). A window of 300 to $500 \mathrm{msec}$ was chosen to analyze this effect.
For the analyses of the CPS window with both SC and OC items, a main effect of PB was found in both the midline, $F(1,27)=30.16, p<.001$, and the lateral analyses, $F(1,27)=35.44, p<.001$. Furthermore, the lateral analysis yielded interactions between the factor PB and ROI, $F(1,27)=9.89, p<.01$, hemisphere and ROI, $F(1,27)=$ $7.30, p<.05$, Electrode, $F(3,25)=7.75, p<.001$, and ROI and Electrode, $F(3,25)=3.93, p<.05$. Separate analyses for the anterior and posterior ROIs yielded a main effect of PB for the anterior ROI, $F(1,27)=31.53, p<.001$, and the posterior ROI, $F(1,27)=17.46, p<.001$. For the posterior ROI, the analyses showed interactions between PB and Hemisphere, $F(1,27)=6.56, p<.05$, and between PB and Electrode, $F(3,25)=10.68, p<.001$. Separate analyses for the two smaller posterior ROIs revealed for the right posterior ROI an effect of $\mathrm{PB}, F(1,27)=36.67$, $p<.001$, and an interaction with Electrode, $F(3,25)=$ 9.64, $p<.001$, and for the left posterior ROI an interaction with Electrode, $F(3,25)=7.07, p<.01$. Analyses for the single electrodes showed a CPS in all electrodes (all $p s<.05)$, except for left posterior electrodes $\mathrm{P} 7$ and PO7 $(p s>.30)$.
Figure 2. Grand average waveforms time locked to the onset of the stressed syllable of the control verb (V1), separately for SC and OC items. A CPS is present for the break condition relative to the no-break condition in the 800- to 1200 -msec window.

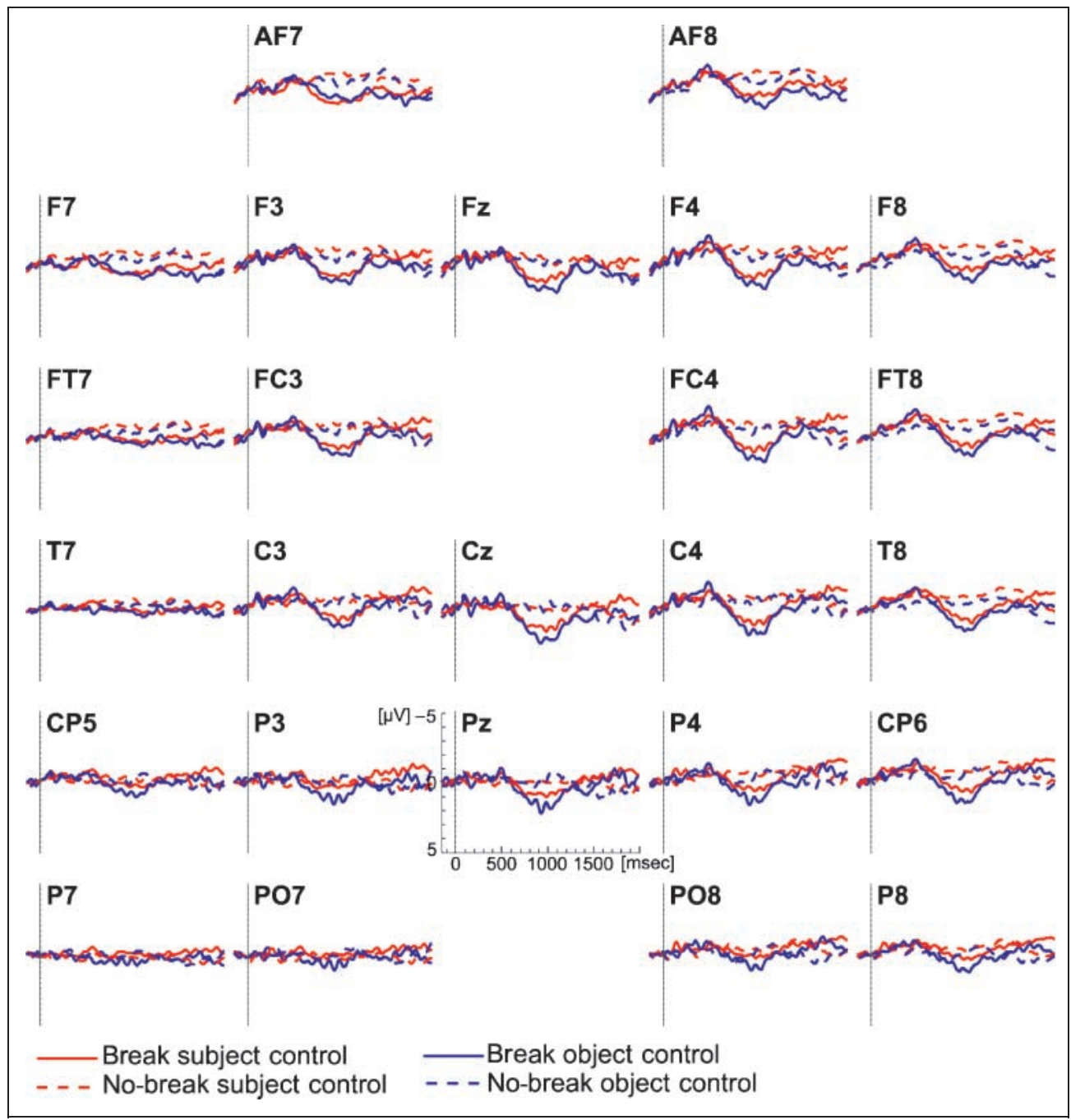


In the overall analyses, no significant interactions between PB and Control were found ( $p s>18$ ) nor any interactions of these factors with Hemisphere, ROI, and/or Electrode (all $p s>$.10). However, Figure 2 suggests a difference in size of the CPS between the SC and the OC items (see, e.g., Cz and P4). ${ }^{3}$ This CPS modulation especially occurs around the peak of the CPS. Therefore, supplementary analyses were done for the four consecutive 100-msec epochs making up the CPS window. The lateral analyses showed an interaction between PB, Control, and ROI for the 900- to 1000-msec window, $F(1,27)=4.45, p<$ .05 , and for the 1000- to $1100-$ msec window, $F(1,27)=$ $5.66, p<.05$. Separate analyses for the anterior and posterior ROIs revealed a $\mathrm{PB} \times$ Control interaction for the posterior ROI in the 1000- to 1100 -msec window, $F(1,27)=$ $5.36, p<.05$. These analyses reveal a small but significant CPS modulation with a smaller CPS for SC than for OC items. $^{4}$

To be certain that both SC and OC items showed a CPS, separate analyses were also performed. These showed the same general pattern for SC and OC items as in the overall analyses. In sum, for both SC and OC items, we found a CPS that was broadly distributed over the whole scalp, however, somewhat attenuated in the left posterior part of the brain.

For the earlier window (300-500 msec), the overall analyses yielded interactions between $\mathrm{PB}$ and the factors Hemisphere, $F(1,27)=5.84, p<.05$, Electrode, $F(3,25)=$ $4.74, p<.01$, and Hemisphere and Electrode, $F(3,25)=$ $4.33, p<.05$. Analyses for the right hemisphere yielded a marginally significant main effect of $\mathrm{PB}, F(1,27)=3.62$, $p=.068$, and for the left Hemisphere a PB $\times$ Electrode interaction, $F(3,25)=7.15, p<.01$. Follow-up analyses revealed an effect of $\mathrm{PB}$ for four right lateral electrodes (FT8, T8, CP6, and P8; ps < .05). Separate analyses for the SC and the OC items showed no effects at the level of the single electrodes for the SC items, whereas the OC analyses showed an effect of PB in the right hemisphere, $F(1,27)=5.09, p<.05$. This early effect, opposite to the CPS, thus seemed to be mainly driven by the OC items and showed a right hemispheric distribution.

\section{Disambiguating Verb}

Figure 3 shows grand average waveforms for the SC items (panel A) and OC items (panel B) for all four conditions, time locked to the onset of the disambiguating verb. Visual inspection of Figure 3 suggests a different pattern for the SC and the OC items. In panel A (SC items), a small N400 effect can be seen for the intransitive condition, both in the break and in the no-break condition. The waveforms for the intransitive break condition (solid red line) are more negative than those for the transitive break condition (dotted red line), and the waveforms for the intransitive no-break condition (solid blue line) are more negative than those for the transitive no-break condition (dotted blue line). In contrast, visual inspection of panel B of Figure 3 (OC items) suggests an N400 effect, but only for the intransitive break condition, as compared with the other three conditions. We analyzed the N400 using the standard 300- to 500-msec time window. The overall analyses yielded a three-way interaction between Control, $\mathrm{PB}$, and Structure in the midline analysis, $F(1,27)=4.29$, $p<.05$. This interaction only approached significance in the lateral analysis, $F(1,27)=3.07, p=.09$.

In the analyses for the SC items, the midline analysis yielded an interaction between Structure and Midline Electrode, $F(2,26)=7.89, p<.01$, and the Lateral analysis revealed an interaction between Structure and ROI, $F(1,27)=8.89, p<.01$, and between Structure, ROI, and Electrode, $F(3,25)=7.57, p<.001$. Separate analyses for the two ROIs revealed a main effect of Structure for the Posterior ROI, $F(1,27)=5.87, p<.05$, and interactions between Structure and Electrode for the Posterior ROI, $F(3,25)=7.89, p<.01$, and Anterior ROI, $F(3,25)=$ 3.41, $p<.05$. Analyses for the single electrodes yielded an N400 effect at four posterior electrodes (P3, Pz, P4, and CP6) and one separate electrode (C4; ps <.05), confirming a typical centro-parietal distribution with a trend toward a right hemisphere dominance. Thus, a typical N400 effect was found for the intransitive as compared with the transitive disambiguating verb, both for the break and no-break condition. Although the size of this N400 effect was small, varying between a mean of 0.29 and $1.00 \mu \mathrm{V}$ for the different electrodes, the analyses show that it is statistically reliable.

In the analyses of the OC items, the midline analysis for the $\mathrm{N} 400$ window yielded a main effect of $\mathrm{PB}, F(1,27)=6.50$, $p<.05$, and a PB $\times$ Structure interaction, $F(1,27)=7.28$, $p<.05$. The lateral analysis also revealed a main effect of $\mathrm{PB}, F(1,27)=4.73, p<.05$, and interactions between $\mathrm{PB}$ and Structure, $F(1,27)=4.44, p<.05$, as well as between PB, Structure, and Electrode, $F(3,25)=5.06, p<.01$. The main effect of $\mathrm{PB}$ was presumably caused by baseline differences due to the presence of a CPS in the break condition, but not in the no-break condition. Therefore, we did separate analyses for the break and no-break conditions, to follow up the $\mathrm{PB} \times$ Structure interaction, using only Structure as critical factor. For the break condition, the midline analysis yielded a main effect of Structure, $F(1,27)=9.84, p<.01$. The lateral analysis revealed a main effect of Structure, $F(1,27)=6.15, p<.05$, as well as interactions between Structure and Electrode, $F(3,25)=3.07$, $p<.05$, and Structure, Hemisphere, ROI, and Electrode, $F(3,25)=3.99, p<.05$. Analyses for the lateral single electrodes showed an N400 effect for five left lateral electrodes (F3, CP5, P3, P7, and C3; ps < .05) and five right lateral electrodes (FC4, CP6, P4, P8, and C4; ps < .05). The N400 effect was thus widely distributed across the scalp and extended to anterior electrodes. For the no-break condition, no effects for the midline or for the lateral analysis were found (all $p s>.20$ ). In sum, a broad N400 effect was found for the intransitive as compared with the transitive disambiguation, only for the break condition. 
Figure 3. Grand average waveforms time locked to the onset of the disambiguating verb (V2), for the SC items (panel A) and the OC items (panel B), for the four different conditions. In panel A (subject control), an N400 effect is present in the 300- to 500-msec window for both intransitive conditions relative to their corresponding transitive conditions. In panel B (object control), an N400 effect is present in the 300- to 500-msec window for the intransitive break condition relative to the transitive break and the two no-break conditions.

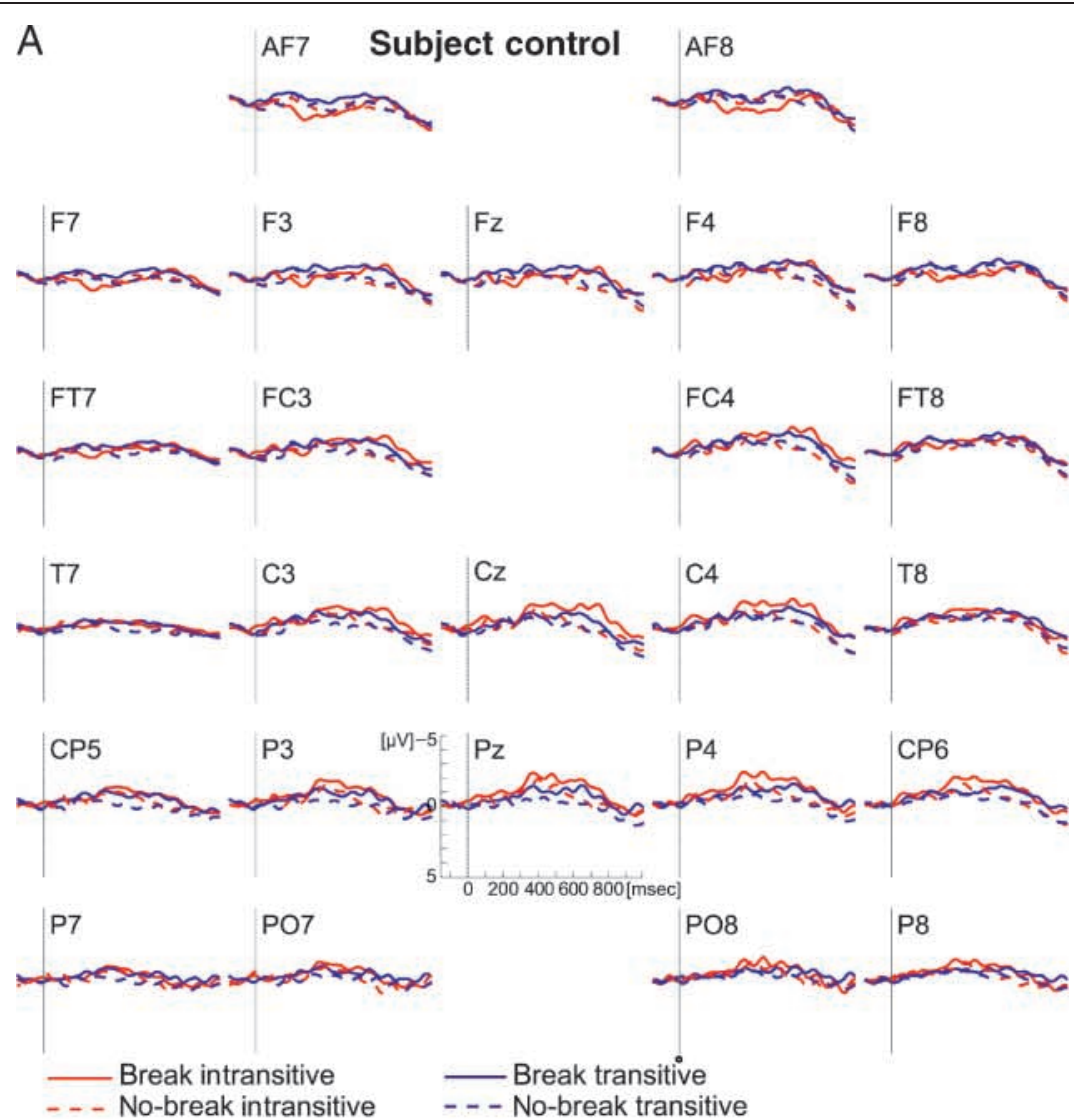

AF7 Object control
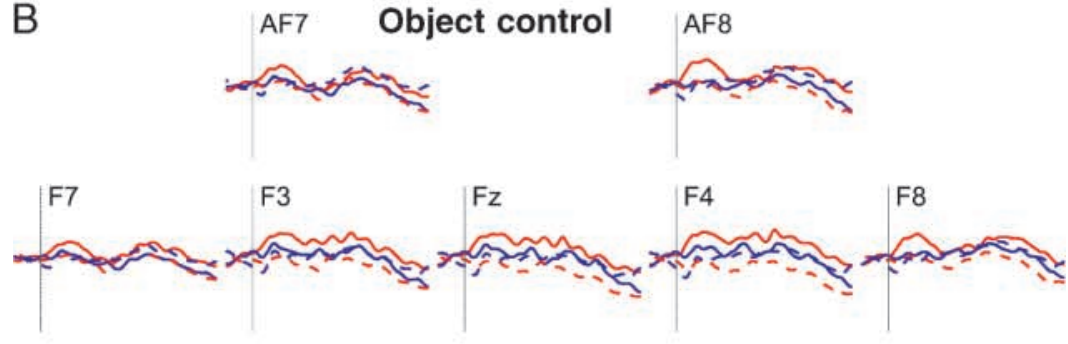

\begin{tabular}{|l|l|l|l|l|} 
FT7 & FC3 & FC4 & FT8
\end{tabular}
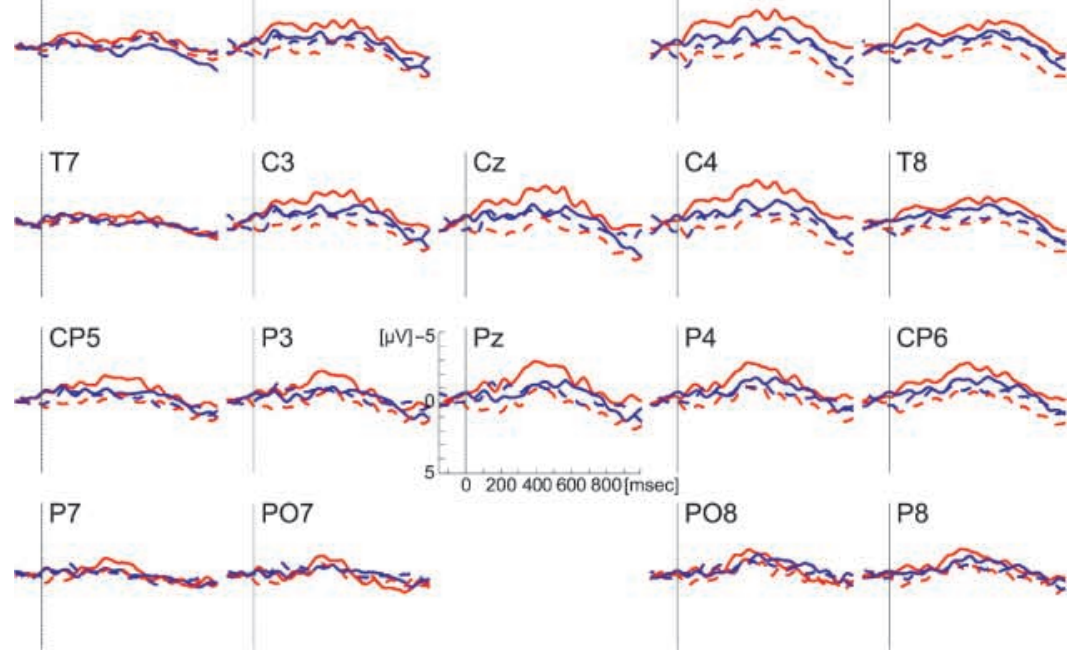


\section{Discussion}

In line with our predictions and consistent with previous studies, a PB gave rise to a CPS (e.g., Kerkhofs et al., 2007; Steinhauer et al., 1999), both for SC and OC items. In addition, we found a modulation of the CPS; it was larger after OC than after SC verbs. We will come back to this CPS modulation in the General discussion section. The CPS had a broad scalp distribution but was most prominent on the right hemisphere and anterior part of the scalp. It started quickly after pause onset and peaked around $500 \mathrm{msec}$ after pause onset. Apparently, in our data, the CPS started only after pause onset, in contrast with Steinhauer (2003) who reports an earlier onset latency of the CPS than the average pause onset. This difference cannot be due to the use of different time-locking points because also with sentence onset as time-locking point (also used by Steinhauer, 2003), the present CPS started after average pause onset (see Appendix B). One explanation for this discrepancy in results could be differences in realization of the $\mathrm{PB}$ by the speakers in the different studies.

Before the CPS, a small, right-lateralized reversed effect was found, which is most clearly seen in the OC items. This has also been found in some earlier studies (Kerkhofs et al., 2007; Pannekamp et al., 2005). It is unclear whether this early effect is part of the CPS complex. Future experiments will have to clarify this question. Finally, following Steinhauer (2003), one could argue that the positivity at the PB is not a real CPS but reflects the average of spread-out P2 components in response to the onset of the acoustic signal after a pause. The following observations counter such a P2 interpretation. First, when filtering the grand average waveforms time locked to sentence onset with a 1-Hz low-pass filter, the P2 elicited by sentence onset disappeared whereas the CPS at the PB remained present. Second, a P2 interpretation would predict a less broad positivity when time locking the ERPs to pause onset than to the other time-locking points because the temporal jitter of the onset of potential P2s should be smaller. However, the positivity time locked to pause onset looks even broader than for the other two time-locking points (see Appendix B). Third, the positivity starts before the average pause offset and thus cannot be a response to the acoustic onset of the word following the pause.

At the disambiguating verb, we demonstrated different patterns of effects for SC and OC items. A general N400 effect for the intransitive as compared with the transitive V2 was found in SC items, whereas OC items showed such an "intransitive N400 effect" only for the break condition, and no effects when no PB was present. These results indicate that the PB affected the processing of the disambiguating V2, but this could only be shown for OC items.

Before turning to the General discussion section, we would like to address two potential problems with the ERP results. First, as indicated in the Results section, the N400 effect at the disambiguating verb of the SC items was statistically reliable but descriptively small. However, one has to bear in mind that descriptively large ERP effects are mostly found in sentences with an outright (semantic or syntactic) violation. In the present study, no outright violations were present; thus, more subtle effects should be expected. This view is confirmed by other studies showing descriptively small but statistically reliable ERP effects in response to relatively subtle manipulations. Van Berkum, van de Brink, Tesink, Kos, and Hagoort (2008) report that a mismatch between the semantic content of a sentence and the speaker information conveyed by the voice (such as I think I am pregnant in a male voice) elicited a small but significant $\mathrm{N} 400$ effect $(0.56 \mu \mathrm{V}$ in the 300 - to 500 -msec window, p. 584). They refer, in this context, to Nygaard and Lunders (2002) who speculate that constraints provided by tone of voice or prosody might, on average, be somewhat weaker than, for example, constraints by lexicalsemantic cues. Chwilla, Kolk, and Mulder (2000, p. 338) demonstrated a small but statistically reliable N400 priming effect (maximally $1.14 \mu \mathrm{V}$ ) for mediated priming in which the prime relates to the target in two steps. Mecklinger, Schriefers, Steinhauer, and Friederici (1995) studied the processing of locally ambiguous sentences varying in semantic plausibility and found a statistically reliable N400 effect of about $1.1 \mu \mathrm{V}$ (p. 488) for verbs that biased toward the garden-path reading of the sentence as compared with the preferred reading.

A second potential problem concerns the possibility that the CPS might complicate the interpretation of the effects at the disambiguating verb. The CPS extends into the disambiguating region of the sentence. This indeed led to main effects of PB in the analyses at the disambiguating region for OC items. However, because we are not interested in main effects of $\mathrm{PB}$, but rather in effects of structure and the interaction between the two factors, this does not pose a problem as long as the size of the CPS does not differ systematically between sentences ending in intransitive and in transitive verbs. Because the same tokens were used for the first parts of the break sentences (up till te, "to") in the transitive and intransitive conditions and the same tokens were used for the first parts of the no-break sentences in the transitive and intransitive conditions, differences between transitive and intransitive conditions at the position of the PB are not very likely. To test this hypothesis empirically, we performed additional analyses for the CPS window including the factor Structure (transitive vs. intransitive). For SC items with a PB, the size of the CPS between the transitive and intransitive condition differed only at one electrode $(\mathrm{Fz})$. The no-break conditions differed at some left posterior electrodes (PO7, Pz, C3, P3, and P7). However, the N400 effect that we found in the SC items at the disambiguation showed a broader centro-parietal distribution, with a right-hemispheric preponderance. For OC items with a PB, no differences in the size of the CPS were present between transitive and intransitive conditions. Therefore, the N400 effect for the intransitive 
break condition cannot have been induced by baseline differences as a consequence of the CPS. The no-break conditions did differ at the offset of V1, at electrodes P8 and FT8. However, for these conditions, we did not find any differences at the point of disambiguation. From these analyses, we conclude that the pattern of results at the disambiguating verb was not caused by differences in the time epoch preceding this verb.

\section{GENERAL DISCUSSION}

\section{Relation between FCT and ERP data}

The results of the FCTs and the ERP experiment show a clear dissociation for the OC items. For these items, a very strong off-line preference for intransitive completions (>90\%) was found. Even with a PB after V1, which should prevent the following NP2 from being regarded as the indirect object of this V1 and thus lead to the expectation of a transitive V2, the percentage of intransitive completions was still 78\%. This stands in sharp contrast with the ERP data. The no-break condition revealed no N400 effect, and thus no indication of the strong intransitive preference from the FCTs. Moreover, in the break condition, an N400 effect for the intransitive disambiguating verb was found, indicating a transitive preference, which is the reverse of the FCT result.

Thus, the question arises why such a strong intransitive preference in the FCTs is not reflected in the on-line ERP data. In an FCT, completion with an intransitive verb requires regarding NP2 as the indirect object of V1. By contrast, completion with a transitive verb requires assuming an implicit indirect object of V1 because NP2 has to be the object of V2. This holds both for SC and OC items. However, if an OC item is completed with a transitive verb, the assumed implicit object of V1 also has to take on the role of the understood subject of V2, whereas this is not the case for SC items. Completion of OC items with a transitive V2 is thus the only case in which a subject for this V2 is not already present in the sentence and thus will have to be imagined by the participant, assuming that production of a verb requires knowing the subject of that verb. In many cases, actively "inventing" a subject in this way will be too much effort and thus will be avoided by the participants. By contrast, in the ERP experiment, no active production is required. Participants only listen to the sentences and process them for meaning. It is possible to understand a sentence like Item 6 without imagining a subject for V2, for example as "The surgeon advised that the woman should receive support."

Furthermore, apart from a general difference in preference, one might wonder why the PB had such a small effect in the FCT as compared with the ERP study. We think differences in task demands in the two types of experiments play a critical role. In the auditory FCT, participants have to listen to the sentence fragment, form an interpre- tation of this fragment, and then actively produce a possible continuation. The last two steps take several seconds. The prosodic information contained in the auditory sentence fragment might not remain active long enough to have a strong influence on the completion. In the ERP study, by contrast, the disambiguation immediately follows the ambiguous part of the sentence, so the prosodic information should be still active at the disambiguation.

These factors might thus explain the dissociation between the off-line FCT results and the on-line ERP results. An important implication of this dissociation is that one should be very careful in generalizing results from off-line experiments to on-line processing.

\section{ERP Results at the Disambiguating Verb}

Given the dissociation between the off-line fragment completion and the on-line ERP data, what can we conclude from the ERP results about on-line processing of these sentences? First of all, the ERP results (as well as the off-line data) clearly indicate different processing patterns for SC and OC items. Therefore, in the following paragraphs, we will discuss them separately.

For the OC items, we found an N400 effect for the intransitive as compared with the transitive disambiguating V2 for sentences with a PB after V1, resembling the classical N400 in showing a bilateral centro-parietal distribution. Because we cannot directly compare these results with the FCTs, we should consider the no-break condition as a baseline. In this condition, no effects were found, indicating that in on-line processing neither a transitive nor an intransitive V2 leads to processing difficulty. The N400 effect in the break condition thus reveals that the PB affects the syntactic analysis pursued in OC items. The PB appears to block an interpretation of NP2 as indirect object of V1, which is eventually confirmed by a transitive, but disconfirmed by an intransitive verb.

For the SC items, an N400 effect for the intransitive as compared with the transitive disambiguating verb was found, resembling the classical N400 in showing a centroparietal distribution and being slightly larger for the right than for the left hemisphere. Because a similar N400 effect was found for both the break and the no-break condition, we cannot conclude that the $\mathrm{PB}$ has an effect on the syntactic analysis in SC items. A possible reason could be that the default preference for SC items does not adhere to the minimal attachment principle, as Steinhauer et al. (1999) assumed, but is reversed, namely, transitive. If a default transitive preference exists for SC items, a $\mathrm{PB}$ after V1 confirms this preference, pointing in the same direction. This might be the reason why it does not have an apparent effect on top of the already present default preference.

There are several indications that such a default transitive preference in SC items indeed exists. First, in the (auditory) FCT data, an overall preference for a transitive completion was found. However, because the results for 
the FCT and the ERP experiments did not match for OC items, one should be careful, also for SC items, in interpreting the FCT results in terms of consequences for on-line processing. However, as we argue above, the overwhelming intransitive preference in the FCT for OC items could be caused by the fact that the subject of V2, the verb that has to be produced in the FCT, is implicit in case a transitive V2 is produced. This argument does not hold for SC items because the subject for V2 is available as NP1 for both an intransitive and a transitive completion. Therefore, there might be less reason to assume a difference in processing between the FCT and the ERP experiments for SC items. Second, in the ERP data, an overall N400 effect for the intransitive as compared with the transitive disambiguation was found. This points to a preference for a transitive disambiguation, although one has to keep in mind that we are dealing here with a comparison between different verbs (transitive versus intransitive). It is possible that differences in length and/or semantics between these types of verbs have led to differences in N400 amplitude. However, since such a general "intransitive" N400 effect was not present for $\mathrm{OC}$ items, we are confident that it was not caused by general verb-class differences between transitive and intransitive verbs. Third, the CPS modulation at the position of the PB could shed more light on this issue. If an SC verb elicits a preference for a transitive V2, this would fit with a PB after an SC verb. A recent study (Kerkhofs et al., 2007) revealed that the CPS was smaller in a situation where the $\mathrm{PB}$ is expected based on information in the preceding discourse than in a situation where there is no expectation. Extrapolating this to the present study, if a PB fits better after an SC than after an OC verb (due to the transitive V2 preference for SC verbs), the CPS should be smaller in the former than in the latter case. This is in line with our finding of a smaller CPS following SC than OC verbs.

What might be the reason for this default transitive preference in SC items? It is possible that SC verbs in general do not frequently have an overt indirect object. If that is the case, an NP after an SC verb will not so easily be regarded as its indirect object but rather as the (direct) object of a later verb. This idea will have to be tested in future studies.

How do the present results relate to those obtained by Steinhauer et al. (1999)? Recall that Steinhauer et al. used only three of the four conditions of the present experiment and primarily focused on one comparison, namely, between the conditions with a PB and a transitive or intransitive verb. They found processing difficulty (in the form of an N400-P600 sequence) for the intransitive as compared with the transitive disambiguating verb. Looking at the same comparison in the present results, we also find processing difficulty (in the form of an N400 effect) for the intransitive disambiguating verb, for both the SC and the OC items. Steinhauer et al. regarded this result as a reversed garden-path effect because they assumed that processing difficulty for the transitive disambiguating verb would be the default. The present
ERP data show that this is not the case. For OC verbs, no processing difficulty for a transitive or an intransitive disambiguation was found in the no-break condition, and for SC verbs, processing difficulty in the no-break condition was found for intransitive verbs, suggesting a default preference in the opposite direction than assumed by Steinhauer et al. Thus, although the ERPs show that the $\mathrm{PB}$ does affect the preference for a transitive or an intransitive disambiguating verb (at least in OC items), it appears that we are not dealing with a "reversed garden-path effect," as had been suggested by Steinhauer et al.

\section{Interpretation of N400 Effect and Absence of P600 Effect}

As an indication of processing difficulty in the present study, we invariably found an N400 effect. N400 effects in response to violations of argument structure have been found before (e.g., Frisch, Hahne, \& Friederici, 2004; Friederici \& Frisch, 2000; Osterhout, Holcomb, \& Swinney, 1994), however, accompanied by a P600 effect. N400 effects in these previous studies are explained, for instance, by the possibility that violations of thematic structure are inherently semantic in nature (Friederici \& Frisch, 2000) or by assuming that this violation makes the sentence very hard to understand on a message level (Osterhout et al., 1994). Steinhauer et al. (1999) interpret the N400 effect as an indication of lexical re-access, which is needed because the verb's argument structure is violated. A recently proposed model of sentence processing, the eADM (Bornkessel \& Schlesewsky, 2006), explains the presence of $\mathrm{N} 400$ effects for these kinds of structures in the following way. Three hierarchical stages in sentence processing are proposed. In the second, most important stage, linking between arguments and verbs takes place. Problems in this stage can lead to an N400 effect. One could argue that in the present experiment, listeners are confronted with a linking problem. The PB leads the listener not to link NP2 to V1. Therefore, it is free to be linked to V2. However, the argument structure of an intransitive V2 is not compatible with this analysis. Therefore, NP2 has to be linked to V1.

This leaves the question why no P600 effect was elicited in the present study. Most studies on violations of argument structure (including Steinhauer et al., 1999) did find a P600 effect (sometimes next to an N400 effect). Steinhauer et al. (1999) interpret the P600 effect in their study as an indication of structural revision. ${ }^{5}$ Following this interpretation, the absence of a P600 effect could indicate that participants did not reanalyze the sentence in the present study. Where might this difference come from? First, in contrast to our materials, the prosody in the sentences of Steinhauer et al. contained a major accent on NP2 in sentences with a PB (p. 195). For isolated sentences, it is possible that this prosodic information (which is not a part of the PB itself), in addition to the PB, could 
also block an interpretation of NP2 as the indirect object of $\mathrm{V} 1$, rendering an intransitive disambiguation even less acceptable. Second, case marking in German forced Steinhauer et al. to use only proper names (which are not case-marked in German), whereas in the present experiment, the stimuli comprised full noun phrases indicating roles and thus more imaginable scenarios. These scenarios might have focused participants' attention on the semantics of the sentence instead of the syntactic structure. Third, Steinhauer et al. presented comprehension questions after 20\% of the sentences. This might have led participants to be more focused on the syntactic structure and relations between arguments because they had to prepare an answer to a possible question about these relations. By contrast, in the present study, participants' main task was to listen for comprehension. This might have lessened the need to understand the structure of the sentences, promoting semantic analysis. A recent study (Friederici, von Cramon, \& Kotz, 2007) supports this argument, also reporting an N400 effect, but no P600 effect, with a task (prosody judgment) that did not direct the participants' attention to the syntactic structure of the sentence, using the same stimuli as Steinhauer et al.

\section{Conclusions}

The present study reveals that items with SC and OC verbs are processed differently. FCTs indicated a strong preference for intransitive completions in OC items and a somewhat weaker preference for transitive completions in SC items. ERP data show a CPS modulation as a function of the type of control verb. At the disambiguating verb of SC items, we found a general N400 effect for an intransitive disambiguation, both in sentences with and without a PB. This contradicts the original assumption of Steinhauer et al. (1999) of a default preference based on minimal attachment. For OC sentences, a mismatch between a PB and a subsequent disambiguating verb elicited an N400 effect in contrast to a situation without a $\mathrm{PB}$. This result reveals that prosodic information can be sufficient to determine the syntactic analysis of a sentence.

\section{APPENDIX A. EXPERIMENTAL SENTENCES}

Sentences with an intransitive V2 are always given first and those with a transitive V2 are given second. Items with the same control verb (V1) are placed after each other.

\section{Subject-control Items}

1. De wetenschapper antwoordt de interviewer te zullen triomferen als hij weer een nieuwe ontdekking heeft gedaan.

2. De wetenschapper antwoordt de interviewer te zullen inlichten als hij weer een nieuwe ontdekking heeft gedaan.
3. De secretaresse antwoordde de conciërge te komen om het probleem op te lossen.

4. De secretaresse antwoordde de conciërge te vragen om het probleem op te lossen.

5. De leerling bekende de leraar te hebben gespiekt tijdens het eerste uur.

6. De leerling bekende de leraar te hebben opgesloten tijdens het eerste uur.

7. De man bekende de vrouw te hebben geflirt met haar beste vriendin.

8. De man bekende de vrouw te hebben bedrogen met haar beste vriendin.

9. De voetballer belooft de trainer te excelleren en de beker te winnen.

10. De voetballer belooft de trainer te verblijden en de beker te winnen.

11. De vrouw beloofde de stervende te zullen rouwen en hem eerbiedig te zullen gedenken.

12. De vrouw beloofde de stervende te zullen begraven en hem eerbiedig te zullen gedenken.

13. De generaal bericht de koning te zullen capituleren en te zullen terugkeren naar het vaderland.

14. De generaal bericht de koning te zullen ondersteunen en te zullen terugkeren naar het vaderland.

15. De voorzitter bericht de leden te zullen vertrekken maar niet zonder een daverend afscheidsfeest.

16. De voorzitter bericht de leden te zullen verlaten maar niet zonder een daverend afscheidsfeest.

17. De dief bezweert de handlanger te vechten en niet zomaar de gevangenis in te gaan.

18. De dief bezweert de handlanger te verraden en niet zomaar de gevangenis in te gaan.

19. De minister bezweert de staatssecretaris te zullen strijden tijdens het komende kamerdebat.

20. De minister bezweert de staatssecretaris te zullen benadelen tijdens het komende kamerdebat.

21. De dokter garandeerde de patiënt te zullen zwijgen en de familie niets te vertellen.

22. De dokter garandeerde de patiënt te zullen beschermen en de familie niets te vertellen.

23. De rector garandeerde de lerares te zullen standhouden tegen de boze ouders.

24. De rector garandeerde de lerares te zullen beschermen tegen de boze ouders.

25. De verdachte getuigt de agent te hebben geslapen en dus onschuldig te zijn aan de misdaad.

26. De verdachte getuigt de agent te hebben beschermd en dus onschuldig te zijn aan de misdaad. 
27. De gedaagde getuigt de rechter te hebben gelogen tijdens de vorige zitting.

28. De gedaagde getuigt de rechter te hebben beledigd tijdens de vorige zitting.

29. De getuige verklaarde de rechter te zullen zwijgen tijdens het proces.

30. De getuige verklaarde de rechter te zullen verrassen tijdens het proces.

31. De minister verklaart de asielzoekers te zullen onderhandelen zodat ze in Nederland kunnen blijven.

32. De minister verklaart de asielzoekers te zullen naturaliseren zodat ze in Nederland kunnen blijven.

33. De tennisser vertelde de trainer te hebben gefaald tijdens de vorige wedstrijd.

34. De tennisser vertelde de trainer te hebben geraakt tijdens de vorige wedstrijd.

35. De wielrenner vertelde de pers te rusten omdat hij erg moe was.

36. De wielrenner vertelde de pers te ontlopen omdat hij erg moe was

37. De vrouw verzekerde de zieke te zullen overnachten in een zaaltje in het ziekenhuis.

38. De vrouw verzekerde de zieke te zullen bezoeken in een zaaltje in het ziekenhuis.

39. De studente verzekerde de docent te zullen feesten als ze haar tentamen zou halen.

40. De studente verzekerde de docent te zullen bedanken als ze haar tentamen zou halen.

41. Het kind vraagt de oppas te mogen winkelen in de grote stad.

42. Het kind vraagt de oppas te mogen bezoeken in de grote stad.

43. De prinses vraagt de kroonprins te zingen op het publieke feest.

44. De prinses vraagt de kroonprins te inviteren op het publieke feest.

45. De bewoonster waarschuwde de inbreker te zullen schreeuwen als hij dichterbij zou komen.

46. De bewoonster waarschuwde de inbreker te zullen belagen als hij dichterbij zou komen.

47. De advocaat waarschuwde de officier te zullen dwarsliggen tijdens het belangrijke proces.

48. De advocaat waarschuwde de officier te zullen dwarsbomen tijdens het belangrijke proces.

49. De hooligan zei de agent te hebben gescholden tijdens de grote vechtpartij.

50. De hooligan zei de agent te hebben uitgescholden tijdens de grote vechtpartij.
51. De bezoeker zei de clown te hebben gelachen tijdens de circusvoorstelling.

52. De bezoeker zei de clown te hebben gewaardeerd tijdens de circusvoorstelling.

53. De studente zweert de professor te zullen blokken om het tentamen te halen.

54. De studente zweert de professor te zullen omkopen om het tentamen te halen.

55. De heks zweert de dwergen te zullen terugkeren als ze weer genoeg kracht heeft.

56. De heks zweert de dwergen te zullen betoveren als ze weer genoeg kracht heeft.

\section{Object-control Items}

57. De huisarts adviseerde de vrouw te sporten om wat gewicht te verliezen.

58. De huisarts adviseerde de vrouw te motiveren om wat gewicht te verliezen.

59. De chirurg adviseerde de vrouw te slapen voor de ingrijpende operatie.

60. De chirurg adviseerde de vrouw te ondersteunen voor de ingrijpende operatie.

61. De commandant beval de soldaat te vuren en het lijk op te ruimen.

62. De commandant beval de soldaat te vermoorden en het lijk op te ruimen.

63. De commissaris beval de agent te spioneren om meer van de zaak te weten te komen.

64. De commissaris beval de agent te bespioneren om meer van de zaak te weten te komen.

65. De koning gebood de ridder te knielen tijdens het uitbundige overwinningsfeest.

66. De koning gebood de ridder te belonen tijdens het uitbundige overwinningsfeest.

67. De hertogin gebood de chauffeur te claxonneren omdat er zich een noodgeval had voorgedaan.

68. De hertogin gebood de chauffeur te verwittigen omdat er zich een noodgeval had voorgedaan.

69. De minister gelastte de toehoorder te vertrekken van de publieke tribune.

70. De minister gelastte de toehoorder te verwijderen van de publieke tribune.

71. De rechter gelast de aanwezigen te zwijgen omdat ze de rechtsgang beletten.

72. De rechter gelast de aanwezigen te verwijderen omdat ze de rechtsgang beletten. 
73. De verpleegster hielp de zieke te lopen omdat hij na de behandeling nog te zwak was.

74. De verpleegster hielp de zieke te vervoeren omdat hij na de behandeling nog te zwak was.

75. De bewaker hielp de crimineel te ontsnappen uit de beruchte gevangenis.

76. De bewaker hielp de crimineel te bevrijden uit de beruchte gevangenis.

77. De bankmedewerker ontraadde de klanten te beleggen in dit slechte economische klimaat.

78. De bankmedewerker ontraadde de klanten te benadelen in dit slechte economische klimaat.

79. De chirurg ontraadde de patiënte te ontbijten voor de zware operatie.

80. De chirurg ontraadde de patiënte te vermoeien voor de zware operatie.

81. De actrice smeekte de regisseur te volharden tot na de première van de film.

82. De actrice smeekte de regisseur te behouden tot na de première van de film.

83. De fan smeekte de zanger te komen om op het feest te zingen.

84. De fan smeekte de zanger te boeken om op het feest te zingen.

85. De dictator verbood de burger te liegen tijdens het belangrijke verhoor.

86. De dictator verbood de burger te pijnigen tijdens het belangrijke verhoor.
87. Het schoolhoofd verbood de kinderen te praten tijdens de rekentoets.

88. Het schoolhoofd verbood de kinderen te verontrusten tijdens de rekentoets.

89. De directeur verplicht de werknemers te pauzeren als ze te veel fouten maken.

90. De directeur verplicht de werknemers te ontslaan als ze te veel fouten maken.

91. De arts verplicht de zieken te rusten voordat ze een grote ingreep ondergaan.

92. De arts verplicht de zieken te ontsmetten voordat ze een grote ingreep ondergaan.

93. De chef verzocht de werknemer te vertrekken omdat het slecht ging met het bedrijf.

94. De chef verzocht de werknemer te ontslaan omdat het slecht ging met het bedrijf.

95. De brandweerman verzoekt de omstanders te wijken om de brandweerauto doorgang te geven.

96. De brandweerman verzoekt de omstanders te verwijderen om de brandweerauto doorgang te geven.

\section{APPENDIX B. THE CPS FOR THREE DIFFERENT TIME-LOCKING POINTS}

Figure B1 shows the CPS in the SC- and OC-control items for the midline electrodes time locked to three different positions in the sentence, namely, sentence onset (panel I), onset of the stressed syllable of V1 (panel II), and offset of V1, which is equivalent with pause onset in the break
Figure B1. Grand average waveforms for the midline electrodes, time locked to sentence onset (panel I), onset of the last stressed syllable before the pause (panel II) and pause onset (offset of V1; panel III), separately for the SC and the OC items, for the break and the no-break conditions. The average onset of the pause of the first $\mathrm{PB}$ in break conditions is indicated with an arrow in panels I and II. A CPS is present for both SC and OC items for all time-locking points.

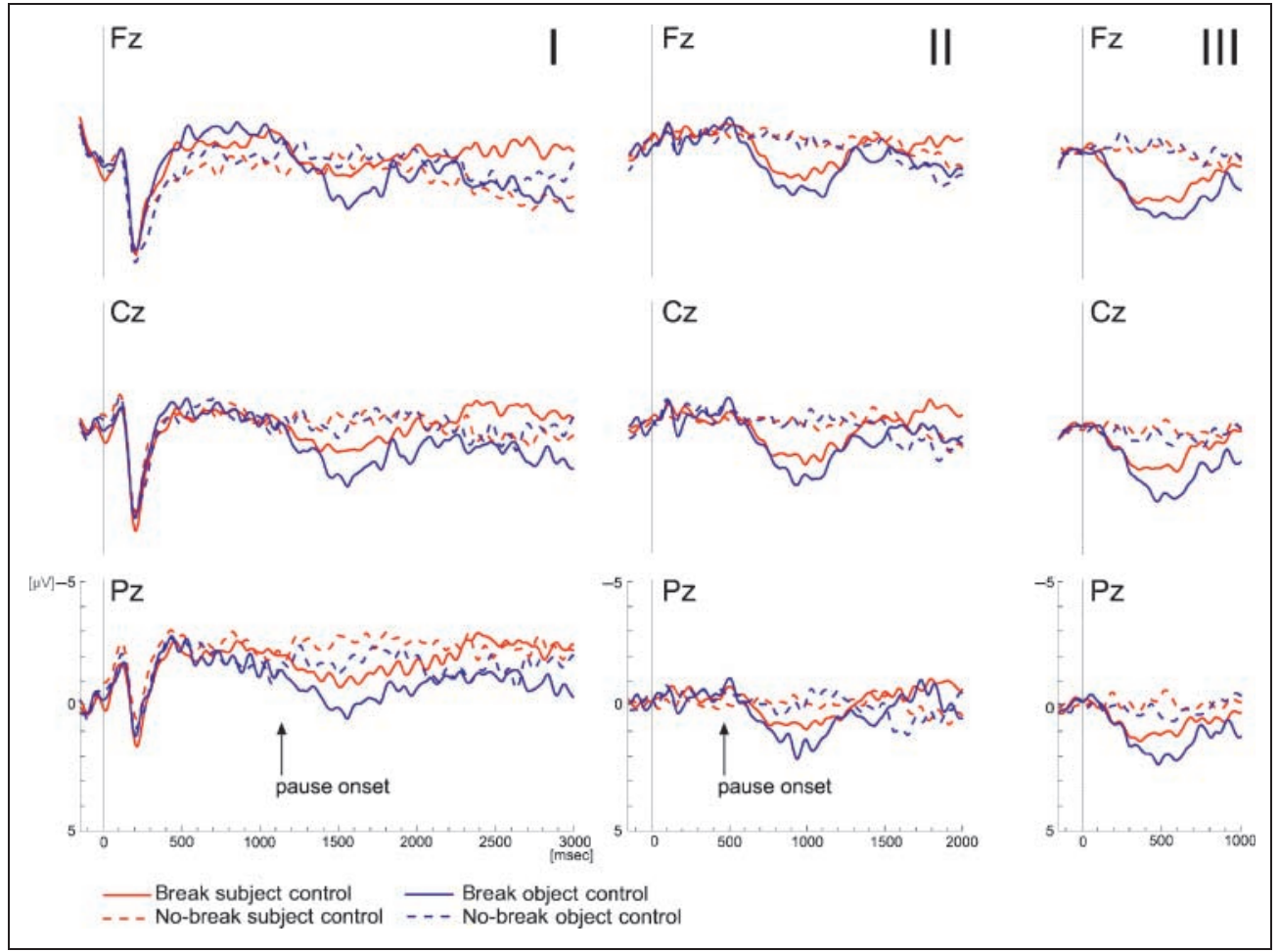


condition (panel III). Visual inspection shows a clear CPS in all three time-locking points, which was confirmed by corresponding analyses. However, for the first two timelocking points, especially sentence onset, a larger epoch had to be extracted from the EEG, which contained more artifacts, more removed trials, and therefore less statistical power. A detailed report of the analyses for the data time locked to sentence onset and offset of V1 can be obtained from the corresponding author.

\section{Acknowledgments}

Portions of this research were presented at the 11th NVP Winter Conference in Egmond aan Zee, 2007, and at the 14th annual conference on Architectures and Mechanisms for Language processing in Cambridge, 2008. We thank three anonymous reviewers for their helpful comments on previous versions of this article, the ERG group of the DCC for technical assistance, and Ilke Kolenbrander for recording the materials.

Reprint requests should be sent to Sara Bögels, Donders Institute for Brain, Cognition and Behaviour, Centre for Cognition, Radboud University Nijmegen, P.O. Box 9104, 6500 HE Nijmegen, The Netherlands, or via e-mail: S.Bogels@donders.ru.nl.

\section{Notes}

1. In two instances, namely, the verbs antwoorden (to answer) and waarschuwen (to warn), the main stress is on the first syllable, but the second syllable is stressed as well. We decided to exclude these items from the acoustic analyses of V1.

2. The time-locking points for the two verbs antwoorden and waarschuwen (see footnote 1) were determined based on individual length differences. These indicated that by far the largest difference in length occurred from the second syllable on. Therefore, for these verbs, the onset of the second syllable was chosen as time-locking point.

3. Grand average waveforms time locked to sentence onset and pause onset descriptively show the same pattern (a larger CPS after OC than SC verbs), see Appendix B.

4. Note that, regarding the acoustic analyses in the Methods section of Experiment 1, this CPS modulation could not be due to differences in the acoustic realization of the PB for the SC and the OC items because no reliable difference in pause length between SC and OC items were present and prefinal lengthening was more pronounced in the SC items than in the OC items, which goes in the opposite direction than the CPS modulation. 5. The $\mathrm{P} 600$ is generally regarded as an indicator of reanalysis or revision, although the form and the function of this reanalysis are a matter of debate (e.g., Vissers, Kolk, van de Meerendonk, \& Chwilla, 2008). However, it should be noted that others have questioned the exact role of the P600 as the sole indicator of reanalysis (for a review, see Kutas, Van Petten, \& Kluender, 2006).

\section{REFERENCES}

Beach, C. M. (1991). The interpretation of prosodic patterns at points of syntactic structure ambiguity: Evidence for cue trading relations. Journal of Memory and Language, 30, 644-663.

Bornkessel, I., \& Schlesewsky, M. (2006). The extended argument dependency model: A neurocognitive approach to sentence comprehension across languages. Psychological Review, 113, 787-821.
Chwilla, D. J., Kolk, H. J., \& Mulder, G. (2000). Mediated priming in the lexical decision task: Evidence from event-related potentials and reaction time. Journal of Memory and Language, 42, 314-341.

Comrie, B. (1985). Reflections on subject and object control. Journal of Semantics, 4, 47-65.

Frazier, L. (1987). Sentence processing: A tutorial review. In M. Colthart (Ed.), Attention and performance XII. Hillsdale, NJ: Erlbaum.

Friederici, A. D., \& Frisch, S. (2000). Verb argument structure processing: The role of verb-specific and argument-specific information. Journal of Memory and Language, 43, 476-507.

Friederici, A. D., von Cramon, D. Y., \& Kotz, S. A. (2007). Role of the corpus callosum in speech comprehension: Interfacing syntax and prosody. Neuron, 53, 135-145.

Frisch, S., Hahne, A., \& Friederici, A. D. (2004). Word category and verb-argument structure information in the dynamics of parsing. Cognition, 91, 191-219.

Hagoort, P., \& Brown, C. (1994). Brain responses to lexical ambiguity resolution and parsing. In K. Rayner, C. Clifton, \& L. Frazier (Eds.), Perspectives on sentence processing. Hillsdale, NJ: Lawrence Erlbaum Associates.

Isel, F., Alter, K., \& Friederici, A. D. (2005). Influence of prosodic information on the processing of split particles: ERP evidence from spoken German. Journal of Cognitive Neuroscience, 17, 154-167.

Kerkhofs, R., Vonk, W., Schriefers, H., \& Chwilla, D. J. (2007). Discourse, syntax, and prosody: The brain reveals an immediate interaction. Journal of Cognitive Neuroscience, 19, 1421-1434.

Kerkhofs, R., Vonk, W., Schriefers, H., \& Chwilla, D. J. (2008). Sentence processing in the visual and auditory modality: Do comma and prosodic break have parallel functions? Brain Research, 1224, 102-118.

Kjelgaard, M. M., \& Speer, S. R. (1999). Prosodic facilitation and interference in the resolution of temporary syntactic closure ambiguity. Journal of Memory and Language, 40, 153-194.

Kutas, M., Van Petten, C., \& Kluender, R. (2006). Psycholinguistics electrified II (1994-2005). In M. A. Gernsbacher \& M. Traxler (Eds.), Handbook of psycholinguistics (2nd ed.). New York: Elsevier Press.

Ladd, D. R., \& Cutler, A. (1983). Introduction. Models and measurements in the study of prosody. In A. Cutler \& D. R. Ladd (Eds.), Prosody: Models and measurements. Berlin: Springer-Verlag.

Marslen-Wilson, W. D., Tyler, L. K., Warren, P., Grenier, P., \& Lee, C. S. (1992). Prosodic effects in minimal attachment. Quarterly Journal of Experimental Psychology, 45, 73-87.

Mecklinger, A., Schriefers, H., Steinhauer, K., \& Friederici, A. D. (1995). Processing relative clauses varying on syntactic and semantic dimensions: An analysis with event-related potentials. Memory \& Cognition, 23, 477-494.

Nygaard, L. C., \& Lunders, E. R. (2002). Resolution of lexical ambiguity by emotional tone of voice. Memory $\&$ Cognition, 30, 583-593.

Osterhout, L., Holcomb, P. J., \& Swinney, D. A. (1994). Brain potentials elicited by garden-path sentences: Evidence of the application of verb information during parsing. Journal of Experimental Psychology: Learning, Memory, and Cognition, 20, 785-803.

Pannekamp, A., Toepel, U., Alter, K., Hahne, A., \& Friederici, A. D. (2005). Prosody-driven sentence processing: An event-related brain potential study. Journal of Cognitive Neuroscience, 17, 407-421.

Rösler, F., Friederici, A. D., Pütz, P., \& Hahne, A. (1993). Event-related brain potentials while encountering semantic and syntactic constraint violations. Journal of Cognitive Neuroscience, 5, 345-362. 
Schafer, A. (1995, March 16-18). The role of optional prosodic boundaries. Paper presented to the Eight Annual CUNY Conference on Human Sentence Processing. Tucson, Arizona.

Schafer, A., Carter, J., Clifton, C., \& Frazier, L. (1996). Focus in relative clause control. Language and Cognitive Processes, 11, 135-163.

Steinhauer, K. (2003). Electrophysiological correlates of prosody and punctuation. Brain and Language, 86, 142-164.

Steinhauer, K., Alter, K., \& Friederici, A. D. (1999). Brain potentials indicate immediate use of prosodic cues in natural speech processing. Nature Neuroscience, 2, 191-196.

Steinhauer, K., \& Friederici, A. D. (2001). Prosodic boundaries, comma rules, and brain responses: The closure positive shift in ERPs as a universal marker for prosodic phrasing in listeners and readers. Journal of Psycholinguistic Research, 30, 267-295.

Stirling, L., \& Wales, R. (1996). Does prosody support or direct sentence processing? Language and Cognitive Processes, 11, 193-212.

Streeter, L. A. (1978). Acoustic determinants of phrase boundary location. Journal of the Acoustical Society of America, 64, 1582-1592.

Van Berkum, J. J. A., van de Brink, D., Tesink, C. M. J. Y., Kos, M., \& Hagoort, P. (2008). The neural integration of speaker and message. Journal of Cognitive Neuroscience, 20, 580-591.

Vasey, M. W., \& Thayer, J. F. (1987). The continuing problem of false positives in repeated measures ANOVA in psychophysiology: A multivariate solution. Psychophysiology, 24, 479-486.

Vissers, C. T. W. M., Kolk, H. H. J., van de Meerendonk, N., \& Chwilla, D. J. (2008). Monitoring in language perception: Evidence from ERPs in a picture-sentence matching task. Neuropsychologia, 46, 967-982.

Warren, P., Grabe, E., \& Nolan, F. (1995). Prosody, phonology and parsing in closure ambiguities. Language and Cognitive Processes, 10, 457-486. 